ZOOLOGIA 27 (6): 939-944, December, 2010

doi: $10.1590 / S 1984-46702010000600015$

\title{
Swimming performance of the small characin Bryconamericus stramineus (Characiformes: Characidae)
}

\author{
Miriam A. de Castro; Hersília de A. Santos²; Francisco A. C. Sampaio' \& Paulo S. Pompeu, 3 \\ 1 Programa de Pós-graduação em Ecologia Aplicada, Departamento de Biologia, Universidade Federal de Lavras. Campus \\ Universitário, Caixa Postal 3037, 37200-000 Lavras, MG, Brazil. \\ ${ }_{2}^{2}$ Departamento de Engenharia Civil, Centro Federal de Educação Tecnológica de Minas Gerais. Campus II, \\ Avenida Amazonas 7675, Nova Gameleira, 30510-000 Belo Horizonte, MG, Brazil. \\ ${ }^{3}$ Corresponding author. E-mail: pompeu@dbi.ufla.br
}

\begin{abstract}
Very little research has been conducted on the swimming capacity of Neotropical fish. The few studies available have focused on large migratory species. The present study used fixed and increasing velocity tests to determine prolonged and sustained speeds of the "pequira", Bryconamericus stramineus Eigenmann, 1908, a small, abundant species found in fish passages implemented at the Paraná basin, Brazil. The results of increasing velocity tests showed significant relationships between critical speeds, total and standard lengths, and body weight. When compared with other Neotropical fish, the "pequira" is able to swim faster than individuals of other species of similar length. The point of change from sustained to prolonged swimming was found to occur at an approximate speed of 8.7 lengths per second. These data provide guidance and criteria for design and proper maintenance of structures such as fishways, fish screens and other systems that aim to facilitate or avoid upstream passages as part of management strategies.
\end{abstract}

KEY WORDS. Critical speed; fish passage; prolonged swimming; Tetragonopterinae.

Issues involving fish life, migrations, and habitats play a key role in decisions concerning existing and new projects in rivers such as hydroelectric plants, water supply, river restoration, and dam removal (KaTOPODIs 2005). The health of fish populations depends on habitat connectivity, the availability of suitable habitats (habitat needs differ between species and life stages), and river flow regimes. The latter provide sediments, ground water, and nutrient circulation, all of which sustain ecological integrity (KATOPODIs 2005). In this context, studies on fish swimming performance are fundamental because they provide guidance and criteria for the maintenance of connectivity in aquatic systems.

There are approximately 4,500 fish species catalogued for South America (ReIs et al. 2003). Despite this great biodiversity, very little is known about the swimming capacities of Neotropical fish (CLAY 1995). The few available studies have focused on large migratory species (SANTOs et al. 2007, 2008) providing criteria for fishway design.

Fish swimming performance can be classified into one of three general categories: sustained, prolonged, or burst swimming. In sustained swimming red muscle fiber activity predominates. This low-speed movement is fueled by energy derived from aerobic metabolism and can be sustained for long periods (at least 200 minutes) without fatigue (BEAmish 1978). By contrast, burst swimming involves primarily white muscle fibers that utilize energy from an anaerobic process, permitting fish to attain relatively high speeds for $<15-20$ seconds (BEAMISH 1978). Prolonged swimming covers a spectrum of velocities between sustained and burst swimming, and both red (aerobic) and white (anaerobic) muscle fibers (BRETT 1964) are used. Prolonged speed is most commonly measured in laboratory studies. Its main subcategory is the critical speed, which was first defined and employed by BRETT (1964). Critical speed corresponds to the maximum speed that a fish can maintain against an increasing flow of changing speed during a pre-determined time interval. Critical speed has been intensely researched since it was initially proposed (HAMmer 1995), allowing powerful comparisons among the swimming capacity of all sorts of species.

In Latin America, fish communities in large rivers are comprised mainly of Siluriformes and Characiformes (Quirós 1989). Tetras (Tetragonopterinae) are among the main representatives of the order Characiformes. They are widely distributed across the continent, inhabiting all large river basins (main channels, tributaries, and floodplains). The pequira, Bryconamericus stramineus Eigenmann, 1908, is an abundant Tetragonopterinae with a geographic distribution that includes the Paraguai, Paraná, and São Francisco river basins (Planquette et al. 1996). It is considered a mid-water swimmer, adapted to currents that range from weak to moderate (FERREIRA 2007). The pequira is small fish (maximum standard length of about $8 \mathrm{~cm}$ ) and lacks commercial value (Ringuelet et al. 1967). However, it is one of the most 
abundant species in the fish passages of the Paraná River basin, such as the Igarapava Power Plant fish ladder passage (Вizzoto 2009) and the Funil Power Plant fish lift passage (GodinHo et al. 2007). For this reason, a better knowledge of the swimming performance of this species is fundamental when trying to design fishways, not only when upstream migration is to be facilitated (when population maintenance depends on migration upriver), but also when it is to be controlled/avoided (when population densities decrease as a result of excessive upstream migration).

The present study used fixed and increasing velocity tests to determine prolonged and sustained speeds for the pequira, B. stramineus.

\section{MATERIAL AND METHODS}

An experimental apparatus was constructed for tests based on Brett's respirometer. It is basically a water tunnel where fish are forced to swim against a water current generated by a centrifugal pump.

The main tube is composed of three parts: a central part, where fish are confined, made of acrylic (A); and two other parts made of PVC. Tubes located anteriorly and posteriorly to the central part reduce the interference of pumps and of the exit apparatus. In the central part of the tube, fish are introduced into a T-junction with an intake positioned upward (B), and removed from the T-junction with an outtake positioned downward. Fish are confined within the central part by two screens $(\mathrm{C})$.

The tunnel apparatus has an electromagnetic flow meter with the same diameter of the test section, to determine water flow (D), which is generated by the pumps (E), and can be changed with a frequency converter (F) (Fig. 1).

All specimens tested were collected in the Grande River during October 2008, downstream from the Funil Power Plant in the state of Minas Gerais. Until testing began, specimens were observed for at least 24 hours within a maintenance system containing water at $21^{\circ} \mathrm{C}$.

In order to avoid loss in swimming capacity, each fish was maintained in the laboratory for no longer than seven days before being tested. Differences due to captivity period, time of test and time of last feeding were avoided by testing all specimens during the day, throughout two days, and under the same feeding conditions. The critical speed tests, or the increasing velocity tests, were performed based on the experimental procedures described by BRETT (1964). A total of 27 specimens were tested, and the fish sample range represented different size classes (Fig. 2).

Fish were habituated to the apparatus water temperature in a small aquarium, where the apparatus water was progressively added. After habituation, each fish was placed into the test section. The test began with the water pumps in low rotation. After five minutes water speed was increased in increments of $5 \mathrm{~cm} / \mathrm{s}$, each increment lasting five minutes. These

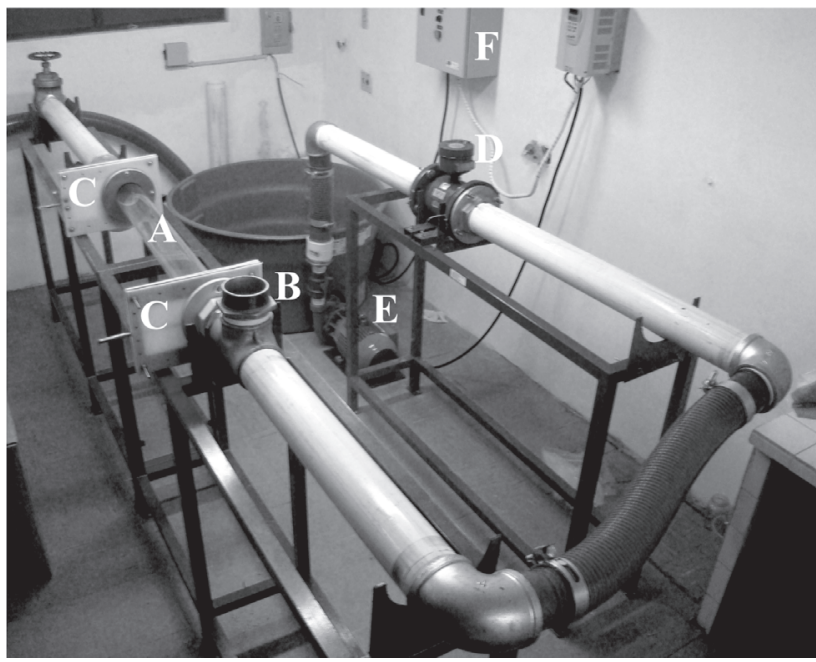

Figure 1. General view of the apparatus with indications of its components.

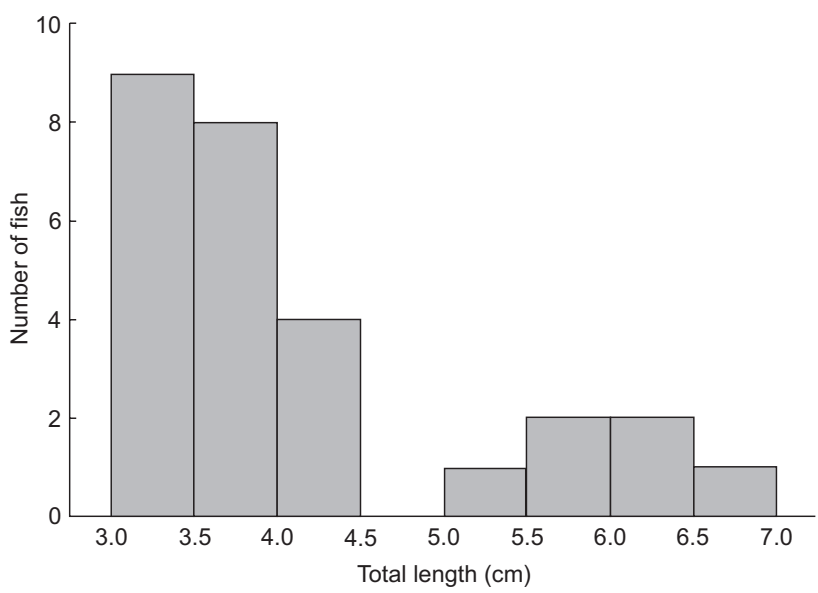

Figure 2. Number of fish per total length class tested for critical speed determination.

increment values were based on the possibilities of speed control permitted by the apparatus and total testing time. The same increments were used in former studies dealing with species from Brazil (SANTOs et al. 2007, 2008), allowing comparisons with our results. After repeated increases in speed, the fish would stop resisting the flow of water due to fatigue. The length of time each fish swam up to the point of fatigue was recorded.

The values of critical speed were calculated according BRETT (1964): $U_{\text {crit5min }}=\mathrm{U} 1+(\mathrm{T} 1 / \mathrm{T} 2 \times \mathrm{U} 2)$, where: $\mathrm{U} 1$ is the fastest velocity maintained for the prescribed time period; T1 is the amount of time to reach the fatigue velocity; $\mathrm{T} 2$ is the prescribed period of swimming (i.e., $5 \mathrm{~min}$ ); and $\mathrm{U} 2$ is the velocity increment (approximately $5 \mathrm{~cm} / \mathrm{s}$ ). 
The prolonged speed tests, or fixed velocity tests, were based on the methodology utilized by BRETT (1967) and Jones et al. (1974). Four different velocities were tested $(0.60,0.65,0.70$, and $0.75 \mathrm{~m} / \mathrm{s})$, relative to the percentage values $(85.7 \%, 92.8 \%$, $100 \%$, and $107 \%)$ of estimated critical speed $(0.7 \mathrm{~m} / \mathrm{s})$ for a specimen with a total length of $5.9 \mathrm{~cm}$. This size was selected for two reasons. First, it occurs frequently in fish captured in shoals of the Grande River. Second, it roughly corresponds to the size when individuals of $B$. stramineus mature, estimated at $4.5 \mathrm{~cm}$ for standard lengths (personal observation).

A total of 19 specimens between 5.3 and $6.4 \mathrm{~cm}$ (four or five per velocity) were tested between April-May 2009 (Fig. 3).

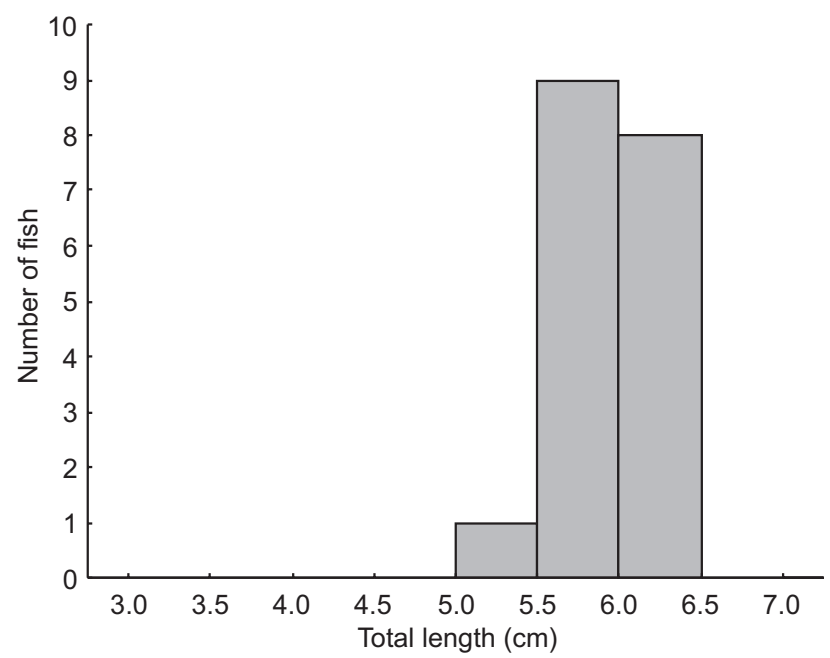

Figure 3. Number of fish per total length class tested for prolonged speed determination.

Each fish was initially subjected to a flow of $0.05 \mathrm{~m} / \mathrm{s}$ for five minutes. Following this, a gradual increase was implemented until the desired speed was reached, for a maximum of five minutes. At this point, no more alterations in water velocity were made and a stop watch was started, in order to measure the fatigue time. Tests had a maximum duration of 200 minutes. This swimming time was adopted because it is considered the limit between prolonged speed and sustained speed (BЕAмISH 1978).

In order to eliminate the influence of fish size on the fatigue time, the test speed for each specimen evaluated was divided by the length of the fish (length/s). During each test performed, parameters concerning water quality, such as dissolved oxygen, temperature, and $\mathrm{pH}$, were monitored. After the tests, each fish was weighed (in grams) and measured (length, height, and width, in centimeters), and the condition factor (K) was calculated.

The solid blocking effect that occurs due to water flow obstruction by the fish's body during the section test was accounted for and corrected for each test according to the equation proposed by PoPe \& HAE (1966).

Relationships between critical speed and fish length, weight, condition factors, and water temperature were tested through linear regressions, with variables transformed into their natural logarithms. The same procedure was adopted for relationship between prolonged speed and fatigue time, as well as the relationship between fatigue time and percentage of fatigued fish. Statistical significance was indicated by P-values of 0.05 or less. The determination coefficient was examined, and our accepted models have the highest coefficient. All analyses were performed using Statistica software.

\section{RESULTS}

The quality of the water in the experimental apparatus, with dissolved oxygen concentrations greater than $5 \mathrm{mg} / \mathrm{l}$, temperatures between $24-28{ }^{\circ} \mathrm{C}$, and $\mathrm{pH}$ levels between 6-9, was considered satisfactory for fish in all tests performed.

The results of increasing velocity tests showed a significant relationship between critical speeds, total and standard lengths, and body weight (Figs 4-6). When associated with the total length, temperature also influenced critical speeds reached by the species $\left(R^{2}=0.68, p=0,027, y=-1.80+0.22 X\right)$, despite slight variations during the tests. However, the condition factor did not explain the critical velocity $\left(\mathrm{R}^{2}=0.023, \mathrm{p}=0.45\right)$.

When compared with other Neotropical species whose critical speed data were obtained under the same experimental conditions, the pequira in our experiment showed superior speeds for specimens with an equivalent total length (Tab. I).

Fatigue times per prolonged speed (fixed velocity tests) class were estimated (Fig. 7) and the point of change from sustained to prolonged swimming (the minimum speed that can be held by a fish for more than 200 minutes) was found to occur at a speed of approximately 8.7 lengths per second. For specimens which have just reached sexual maturity $(5.9 \mathrm{~cm})$, this speed is approximately $0.51 \mathrm{~m} / \mathrm{s}$.

Table I. Statistical aspects of known critical speed curves for neotropical species, and velocity (lengths per second) for the first maturation total length $(\mathrm{ml})$.

\begin{tabular}{llcccccc}
\hline \multicolumn{1}{c}{ Species } & $\mathrm{N}$ & Equation & $\mathrm{R}^{2}$ & $\mathrm{P}$ value & $\mathrm{mL}(\mathrm{cm})$ & Velocity & Author \\
\hline L. reinhardti & 25 & $\mathrm{~V}=3.5+0.5 \mathrm{~L}$ & 0.40 & $<0.001$ & 16 & $8.25 \mathrm{~L} / \mathrm{s}$ & SANTOs et al. 2007 \\
P. maculatus & 24 & $\mathrm{~V}=2.8+0.7 \mathrm{~L}$ & 0.45 & $<0.001$ & 23 & $6.09 \mathrm{~L} / \mathrm{s}$ & SANTOs et al. 2008 \\
B. stramineus & 27 & $\mathrm{~V}=1.2+1.7 \mathrm{~L}$ & 0,60 & $<0,001$ & 6 & $11.86 \mathrm{~L} / \mathrm{s}$ & Present study \\
\hline
\end{tabular}



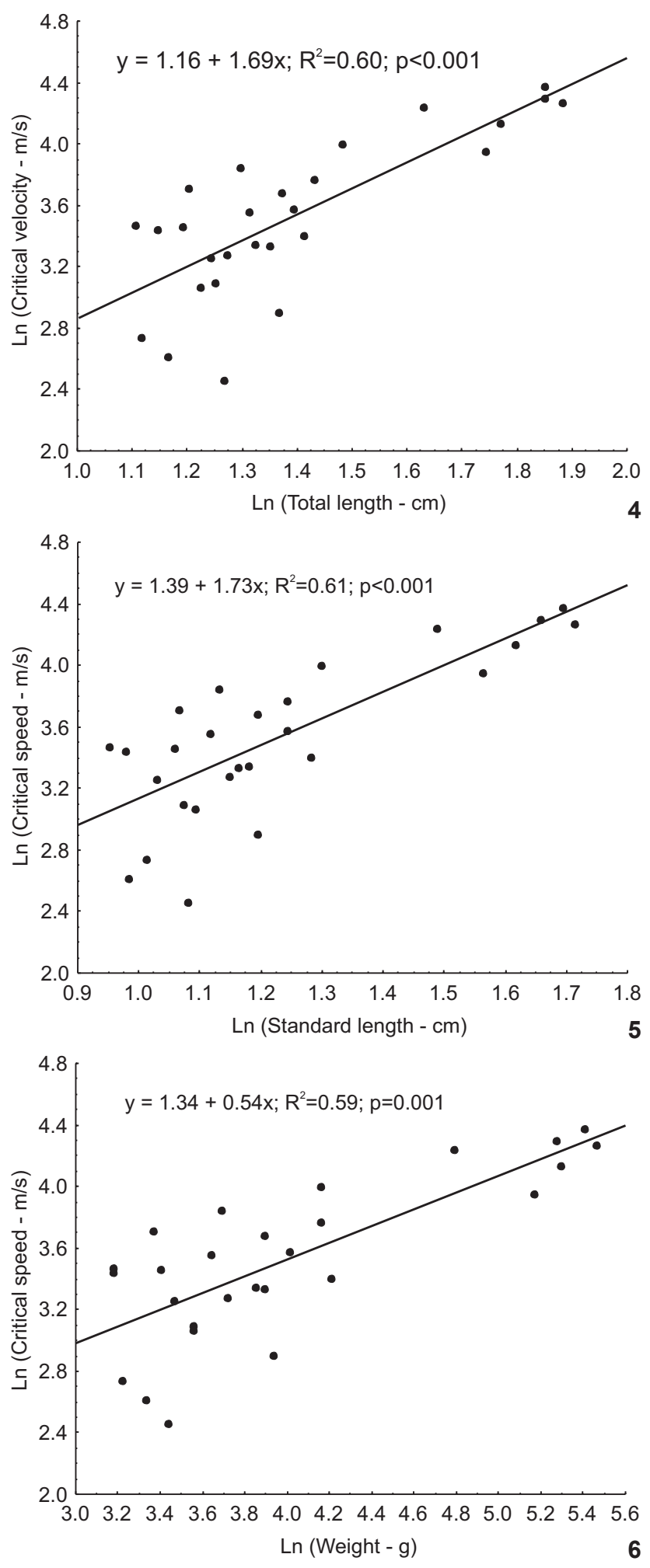

Figures 4-6. Relationship between critical speed and total length, standard length and weight for $B$. stramineus.

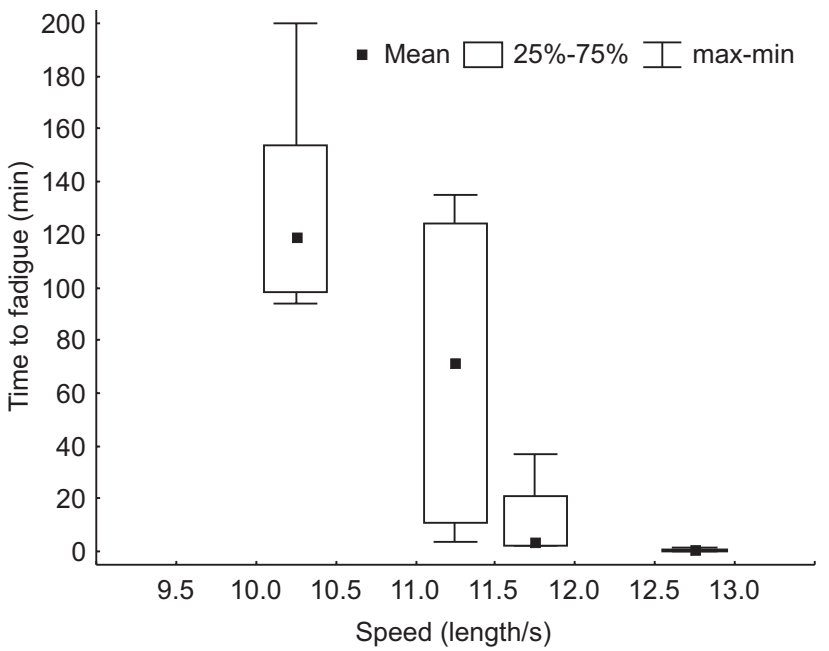

Figure 7. Time to fatigue per speed class (length/s) for $B$. stramineus.

\section{DISCUSSION}

The results obtained in the present study for the pequira, $B$. stramineus, were the first for this genus involving speed measurements in a laboratory. Additionally, our experiments have provided the first available swimming performance data for a Neotropical small fish species.

The strong relationship between critical speed and total length reflects the importance of the caudal peduncle and the caudal fin, an important propulsion element in fish with a subcarangiform pattern of locomotion (Wевв 1994), as in the case of the Tetragonopterinae. The relationships between critical speed and standard length and weight were similar, indicating that weight and length measurements are strongly correlated. These relationships are also reflected in a non-significant relationship between critical speed and the condition factor, because fish in our experiment were subjected to the same conditions.

Compared to other critical speed studies on other types of fish (Jones et al. 1974, SANTOS et al. 2007, 2008), the curves obtained for the pequira showed greater $\mathrm{R}^{2}$ values, despite the equivalent number of specimens tested in all studies. However, it is important to point out that $5 \mathrm{~min}$ is a shorter duration time than that used in most fish swimming studies, and as a consequence of that, our values for the critical speed may be a little over-estimated.

The drag force on a body is strongly correlated with hydrodynamic aspects of the body (MATTHEws 1998) and is influenced by the velocity of flowing currents. Body shape is a major limiting factor to habitat occupancy; the shape of the body influences its locomotive abilities, especially where foraging and escape from predators are concerned (Neves \& MonTeiro 2003). Faster environments, such as those occupied by $B$. stramineus (FERREIRA 2007), are assumed to be more restrictive 
to the fish species, because mobility and maintenance of body positions in these habitats require more energy input (Lamouroux et al. 2002, Casatti \& CAstro 2006). For this reason, lower intra-specific variation is expected in these environments and explains the strong relationships that we have found.

A comparison between available data also indicates that larger species have a slower relative speed, in lengths per second. If we consider that these species could eventually be sympatric, this relationship should be expected because smaller species must deal with water velocities that are proportionally higher.

Critical speed is a powerful tool for comparing swimming capacities among species (Hammer 1995), but its use is limited because critical speeds are lower than speeds achieved in open channels (PeAKe 2004); additionally, critical speed has little biological significance. Endurance tests provide a more accurate measure of the swimming ability of fish species for certain time spans and at a given speed (KoloK 1992). Thus, it is common to use prolonged speeds in fish passage mechanisms design (KATOPODIs 2005), allowing researchers to gather specific information on how long (endurance times) and how far (swimming distances) a particular fish can swim against given water velocities (Katopodis 1992), since it is possible to create a model for the relationship between maximum traversable water velocity (cm/s) and length of fishway (m) (ADAMs et al. 2000).

Fish ladders already implemented in Brazil do not seem to impose an obstacle for the "pequira", which is one of the country's most abundant species, prevailing over migratory species populations such as the "dourado" (Salminus spp.), "curimatã" (Prochilodus spp.), and "mandi" (Pimelodus maculatus Lacepède, 1803) (Godinho et al. 2007, Bizzoto 2009). For this reason, it is likely that fish ladders are providing water velocity regions with speeds of at least $0.5 \mathrm{~m} / \mathrm{s}$, the pequira's estimated prolonged swimming speed.

Although other habitat factors (such as substrate, water quality, and depth) have an influence in the presence of a given fish (Bover 1986), velocity is the primary factor that can explain the low selectivity of the pequira in Brazilian fishways.

However, because $B$. stramineus is a non-migratory species inhabiting fast flowing waters, most fish passages may be functioning as an ecological trap for them, as defined by Pelicice $\&$ Agostinho (2008). This is possible because the upstream passage is not required for the species' reproduction, the downstream passage is generally limited (Pompeu et al. 2004), and the reservoir represents a less profitable habitat than the river downstream. Therefore, information on percentages of fatigued fish during a given swimming time and water velocity might be the most relevant to ascertain the factors affecting the swimming performance and management of the species.

From the data obtained, it is possible to estimate that velocities of 11.9 and 12.7 lengths per second can completely limit the passage of a specimen, in obstacles where the fish last at least seven and three minutes, respectively.
Due to the lack of basic information on the biology of Neotropical fish species, important biological factors were not considered in South American fishway projects. However, the high swimming capacity of the pequira can explain the success of this species in ascending fishways constructed in Brazil.

The data obtained for $B$. stramineus represent an important contribution to the knowledge about the species. This data provides guidance and criteria for designing and proper maintenance of several structures, such as fishways, fish screens, and other systems, in order to facilitate or avoid upstream passages according to management strategies.

\section{ACKNOWLEDGEMENTS}

We are grateful to FAPEMIG for financial support. Special thanks to Rafael Couto, student who helped us with the experimental tests.

\section{LITERATURE CITED}

Adams, S.R.; J.J. Hoover \& K.J. Kilgore. 2000: Swimming performance of Topeka shiner (Notropis Topeka) an endangered Midwestern minnow. The American Midland Naturalist 144: 178-186.

BEAMISH, F.W.H. 1978. Swimming capacity, p. 101-187. In: W.S. Hoar \& D.J. Randall (Eds). Fish Physiology. New York, Academic Press.

Bizzotтo, P.M. 2009. Influence of seasonal, diel, lunar, and other environmental factors on upstream fish passage in the Igarapava Fish Ladder, Brazil. Ecology of Freshwater Fish 18: 461-472.

Bovee, K.D. 1986. Development and evaluation of habitat suitability criteria for use in the instream flow incremental methodology. U.S. Fish and Wildlife Service Biological Report 86: 1-235.

BRETT, J. R. 1964. The respiratory metabolism and swimming performance of young Sockeye Salmon. Journal of the Fisheries Research Board of Canada 21: 1183-1226.

BRETT, J.R. 1967. Swimming performance of Sockeye Salmon (Oncorhynchus nerka) in relation to fatigue time and temperature. Journal of the Fisheries Research Board of Canada 21: 1731-1741.

Casatti, L. \& R.M.C. Castro. 2006. Testing the ecomorphological hypothesis in a headwater riffles fish assemblage of the rio São Francisco, southeastern Brazil. Neotropical Ichthyology 4: 203-214.

Clay, C.H. 1995. Design of fishways and other fish facilities. Boca Raton, CRC Press.

Ferreira, K.M. 2007. Biology and ecomorphology of stream fishes from the Mogi-Guaçu basin, Southeastern Brazil. Neotropical Ichthyology 5: 311-326.

Godinho, A.L.; Z. Silva; M.O.B. Silva \& A.L.C. Braga. 2007. Influence of abiotic factors on the fish passage at the Funil Fish Lift, Grande River, Brazil, p 1-6. In: P. Dos S. Pompeu; 
H.A. Santos \& C.B.M. Alves (Eds). Proceeding of the International Symposium on Fish Passages in South America. Lavras, Universidade Federal de Lavras.

Hammer, C. 1995. Fatigue and exercise tests with fish. Comparative Biochemistry and Physiology 112: 1-20.

Jones, D.R.; J.W. Kiceniuk \& O.S. BAmford. 1974. Evaluation of the swimming performance of several fish species from the Mackenzie River. Journal of the Fisheries Research Board of Canada 31: 1641-1647.

Katopodis, C. 1992. Introduction to Fishway Design. Winnpeg, Freshwater Institute.

Katopodis, C. 2005. Developing a toolkit for fish passage, ecological flow management and fish habitat works. Journal of Hydraulic Research 43: 451-467.

Kolok, A.S. 1992. The swimming performance of individual largemouth bass (Micropterus salmoides) are repeatable. Journal of Experimental Biology 170: 265-270.

Lamouroux, N.; N.L. Poff \& P. L. Angermeier. 2002. Intercontinental convergence of stream fish community traits along geomorphic and hydraulic gradient. Ecology 83: 1792-1807.

Matrhews, W.J. 1998. Patterns in Freshwater Fish Ecology. New York, Chapman \& Hall.

Neves, F.M. \& L.R. Monteiro. 2003. Body shape and size divergence among populations of Poecilia vivipara in coastal lagoons of souht-eastern Brazil. Journal of Fish Biology 63: 928-941.

Peake, S. 2004. An evaluation of the use of critical swimming speed for determination of culvert water velocity criteria for smallmouth bass. Transaction of the American Fisheries Society 133: 1472-1479.

Pelicice, F.M. \& A.A. Agostinho. 2008. Fish-passage facilities as ecological traps in large neotropical rivers. Conservation Biology 22: 180-188.

Submitted: 11.III.2010; Accepted: 19.IX.2010.

Editorial responsibility: Carolina Arruda Freire
Planquette, P.; P. Keith \& P.Y. Le Bayl. 1996. Atlas des poissons d'eau douce de Guyane. Paris, Museum National D’Histoire Naturelle. Service du Patrimoine Naturel, Institut D'Ecologie et de Gestion de la Biodiversité, Collection du Patrimoine Natural 22.

Pompeu, P. dos S.; V.P. Ferreira; H.F. Silva \& C.B. Martinez. 2004. Evaluation of downstream fish passage through Santa Clara Power Plant Dam, Minas Gerais, Brazil. In: Proceedings of Fifth International Symposium on Ecohydraulics, Aquatic Habitats: Analysis \& Restoration. Madrid, International Association of Hydraulic Engeneering and Research,vol 2, p. 999-1003.

Pope, A. \& W.H.J. Hae. 1966. Low-Speed Wind Tunnel Testing. New York, John Wiley and Sons.

Quirós, R. 1989. Structures assisting the migrations of nonsalmonid fish: Latin America. Rome, FAO.

Reis, R.E.; S.O. Kullander \& C.J. Ferraris Jr. 2003. Check list f the freshwater fishes of South and Central America. Porto Alegre, EDIPUCRS.

Ringuelet, R.; R. Aramburu \& A.A. De Aramburu. 1967. Los peces argentinos de água dulce. La Plata, Comission de Investigacion Científica.

Santos, H. de A.; P. dos S. Pompeu \& C. B. Martinez. 2007. Swimming performance of the migratory Neotropical fish Leporinus reinhardti (Characiformes: Anostomidae). Neotropical Ichthyology 5: 139-146.

Santos, H. de A.; P. dos S. Pompeu; G.S. Vicentini \& C.B. Martinez. 2008. Swimming performance of the freshwater neotropical fish: Pimelodus maculatus Lacepède, 1803. Brazilian Journal of Biology 68: 433-439.

Wевв, P.W. 1994. The biology of fish swimming, p. 45-62. In: L. Maddock; Q. Bone \& J.M.V. RaYner. (Eds). Mechanics and physiology of animal swimming. Cambridge, Harvard University Press. 